ROCZNIKI TEOLOGICZNE

Tom LXVIII, zeszyt $1-2021$

DOI: https://doi.org/10.18290/rt21681-5

IRENA SASZKO

\title{
PRZEWODNICTWO DUCHOWE W ŚWIETLE NAUCZANIA ŚW. TEOFANA PUSTELNIKA
}

\author{
SPIRITUAL GUIDANCE \\ IN THE LIGHT OF THE TEACHING OF ST. THEOPHAN THE RECLUSE
}

\begin{abstract}
A b s tra ct. St. Theophan the Recluse (1815-1894) was a Russian ascetic, recluse, and at the same time a bishop and theologian. In his sermons, as well as in his numerous correspondence, he encouraged the use of spiritual guidance given to the faithful by monks, nuns and priests. He also gave advices to spiritual guides on how to carry out the ministry they had been called to. Referring to the tradition of the Church, he proclaimed that the relationship between the elder and his disciples should be based on a close and cordial frienship. If someone is unable to find an experienced spiritual father, his friends may be helpful on the path to eternity.
\end{abstract}

Key words: St. Theophan the Recluse; spiritual guidance; the elder; friend.

Dane przez Zbawiciela przykazanie, abyśmy byli doskonali, jak Ojciec nasz Niebieski jest doskonały (por. Mt 5, 48), nie jest zadaniem nieosiągalnym. Bowiem - jak nauczał św. Grzegorz z Nazjanzu - doskonałość człowieka, w odróżnieniu od doskonałości Boga, polega nie na osiągnięciu zamierzonego celu, lecz na nieustannym dążeniu do zdobycia cnót i poszukiwaniu Bożej obecności ${ }^{1}$. Na tej drodze niekończącego się rozwoju duchowego osoby ludzkiej czyhają liczne demony. $Z$ tego powodu walka duchowa toczona bez wsparcia doświadczonego mistrza jest skazana na przegraną. Wiedzieli o tym już pierwsi chrześcijanie. Dlatego poszukiwali kogoś, kto najpierw wprowadziłby ich we

Dr IRENA SASZKo - Katedra Filologii Słowiańskiej Chmielnickiego Uniwersytetu Narodowego; adres do korespondencji: вул. М. Залізняка 14/2, кв. 121, м. Хмельницький 29027, Ukraina; e-mail: irenasaszko@gmail.com. ORCID: https://orcid.org/0000-0003-2077-257X.

${ }^{1}$ Por. Л. КАРФИКОВА, Святитель Григорий Нисский. Бесконечность Бога и бесконечный путь к Нему человека, перевод И. Бей, Дух і Літера, Киев 2012, s. 236-237. 
wspólnotę wiary, a następnie nauczyłby życia zgodnie z Ewangelią. Początki przewodnictwa duchowego $\mathrm{w}$ formie indywidualnego towarzyszenia sięgają IV wieku. W tym czasie, po prześladowaniach, zaczyna być praktykowane życie monastyczne w Egipcie, na Bliskim Wschodzie oraz w Azji Mniejszej. Monastycyzm był i ciągle jest powiązany z przewodnictwem duchowym oraz terapią duchową, z której mogą czerpać zarówno mnisi, jak i ludzie świeccy².

„Rozkwit [rosyjskiego starczestwa] przypada na koniec XVIII w., osiąga swoje apogeum w wieku XIX oraz trwa bez przerwy aż do rewolucji 1917 roku"3. W ciągu owych 150 lat prawie w każdym monasterze i skicie na terenach ówczesnego Imperium Rosyjskiego można było spotkać doświadczonego przewodnika duchowego, zwanego starcem (gr. geron, cs. stariec), który niczym latarnia przyświecał licznym wiernym na drogach ich duchowych wędrówek. Starcy czuwali nad powierzonymi im przez Boga dziećmi duchowymi, aby podążając wąską, a czasami nawet bardzo stromą ścieżką do Nieba, nie ulegli złudnym pokusom demonów, a przez to nie utracili uzdrawiającej i zbawczej relacji z Bogiem. Jednym z doświadczonych przewodników duchowych - zarówno dla mnichów i mniszek, jak i świeckich prawosławnych chrześcijan w XIX-wiecznej Rosji-był św. Teofan Pustelnik (1815-1894). Ów święty biskup Teofan nie lubił, gdy nazywano go pustelnikiem. Wyjaśniał, że powodem jego zamknięcia się w celi było pisanie książek. Niemniej szeroka korespondencja, którą prowadził, świadczy o tym, że był prawdziwym przewodnikiem duchowym dla wielu osób ${ }^{4}$. Chociaż nie przeceniał znaczenia życia pustelniczego, twierdząc, iż dzięki żarliwej modlitwie prawdziwą pustelnię można wybudować we własnym sercu, a bez modlitwy nawet do zamkniętej celi da się wprowadzić cały świat, to jednak gorliwie zalecał znalezienie mądrego ojca duchowego lub matki duchowej ${ }^{5}$. Nauczał, że „,[...] skrytość w życiu codziennym to rzecz nie najgorsza, lecz w duchowym - najbardziej niebezpieczna. Koniecznie należy mieć kogoś, z kim można byłoby porozmawiać o tym, nie tylko co jest na zewnątrz, a przede wszystkim o tym, co kryje się wewnątrz. [...] Wówczas wszystkie podstępy demonów natychmiast zostaną rozproszone"6.

\footnotetext{
${ }^{2}$ Por. W. MisIJuK, Przewodnictwo duchowe w monastycyzmie prawosławnym, Prawosławna Diecezja Lubelsko-Chełmska, Lublin 2014, s. 57-66. Por. T. MERTON, Kierownictwo duchowe i medytacja, thum. W. Grzybowski, Wydawnictwo M, Kraków 1995, s. 9.

${ }^{3}$ В. Лосский, Оптинские стари̧ь, w: TENŻE, На стражи истины, Стретенский монастырь, Москва 2007, s. 22.

${ }^{4}$ Por. Г. ФлОРОвСкий, Пути русского богословия, Краматорск: Издательство «Тираж-51» 2012, s. 579.

${ }^{5}$ Por. tamże, s. 580.

${ }^{6}$ Святитель Феофан Затворник, Что есть духовная жизнь и как на нее настроиться? Собрание писем, Правило веры, Москва 2017, s. 287-288.
} 


\section{ZNACZENIE PRZEWODNICTWA DUCHOWEGO}

Ojcostwo lub macierzyństwo duchowe na dobre zakorzeniło się wśród chrześcijan prawosławnych, a obecnie też na nowo zyskuje swoją, niegdyś utraconą, popularność w chrześcijaństwie zachodnim. Już św. Klemens Aleksandryjski zalecał swoim słuchaczom znalezienie sobie przewodnika duchowego - osobę mądrą i Bożą, która „czuwałaby nad nami i leczyła nas" "7. Autor Wychowawcy wyjaśniał, iż rola przewodnika „polega na udoskonaleniu duszy: nauczyciel ma nie tylko kształcić czy udzielać informacji, lecz przede wszystkim ma nauczać życia cnotliwego"8. Jego zadaniem ma być stawanie się dla swoich uczniów prawdziwym mistrzem (gr. didaskalos), a nie tylko zwykłym pedagogiem (gr. paidagogos). Przyswojenie ogromnych pokładów wiedzy duchowej stanie się możliwe jedynie wtedy, gdy uczeń wejdzie w relację ze swoim mistrzem i łączyć ich będzie głęboka wspólnota (gr. koinonia) duchowa ${ }^{9}$. „Przewodnictwo duchowe polega na prostowaniu ścieżek Pańskich w ludzkich sercach, usuwaniu przeszkód dla Chrystusa, Który pośpiesza do każdego człowieka z Dobrą Nowiną" 10 .

Święty Teofan Pustelnik wyróżniał trzy rodzaje przewodnictwa duchowego: duszpasterstwo cerkiewne, przełożeństwo monastyczne oraz „starczestwo", czyli ojcostwo duchowe w odniesieniu do konkretnych osób ${ }^{11}$. Zatem starcem (gr. geron) - zdaniem św. Teofana - niekoniecznie musi być kapłan czy osoba mająca schimę mniszą. Może nim być również osoba świecka, jeśli prowadzi wystarczająco głębokie życie duchowe ${ }^{12}$. Osobę taką ma cechować przede wszystkim wielkie rozmiłowanie w Słowie Bożym oraz w pismach Ojców Kościoła, a jej najbardziej rozpoznawalną cnotą ma być roztropność, zdobyta poprzez wytrwałą walkę duchową, wielką pokorę i nieustanną modlitwę. W formacji duchowej istotna jest miłość do Ewangelii oraz zdobywanie mądrości Ojców Kościoła poprzez czytanie ich pism. Zażyłość ze Słowem Bożym otwiera na łaskę rozeznawania duchowego (gr. diakrisis) i mądrość serca ${ }^{13}$.

\footnotetext{
${ }^{7}$ Р.Л. ВілКеН, У пошуках обличчя Божсого. Введення у богослов'я ранньої Церкви, Видавництво українського католицького університету, Львів 2005, s. 261.

8 Tamże, s. 262.

${ }^{9}$ Por. Ф. НемьРини, От отиа к сыну. Беседы о рискованном деле воспитания, перевод. Е. Бровко, Дух і Літера, Киев 2015, s.189.

${ }^{10}$ В. Зелинский, Дружба как духовничество, w: Дружба: ее формы, испытания и дары, ред. К. Сигов, Дух і Літера, Киев 2008, s. 58.

${ }^{11}$ Por. Святитель Феофан Затворник, Малье произведения, Правило веры, Москва 2018, s. 147.

12 Tamże, s. 111.

13 Tamże, s. 158, 170-172.
} 
Święty Teofan Pustelnik nie tylko czytał w oryginale teksty Ojców Kościoła, lecz także tłumaczył je na język rosyjski. Pokornie wyznawał, iż „samowystarczalność” oraz „pewność siebie” zawsze bardzo zgubnie działają na osobę ludzką, a tym bardziej na chrześcijanina, który rozpoczyna swą drogę duchową ${ }^{14}$. Jego zdaniem osiągnięcie rozwoju duchowego wymaga znalezienia mądrego starca, który byłby zarazem „lekarzem, doradcą, mistrzem, człowiekiem mającym wypisaną na swym sercu Księgę Życia, pouczonym przez Ducha Świętego, beznamiętnym oraz żyjącym w Bogu"15. Podtrzymywanie i rozwój życia duchowego wymaga zarówno doświadczonych terapeutów opatrujących rany naszych dusz, jak i prawdziwych nauczycieli nieustannej modlitwy i ascezy ${ }^{16}$. „Człowiek sam z siebie nie jest w stanie zrozumieć, co mu dolega. Postąpi więc bardzo mądrze, gdy zwróci się do swojego przewodnika duchowego z prośbą: «Spójrz, proszę, i powiedz, co się ze mną dzieje?»”17. „Jako widzący, starzec natychmiast zdiagnozuje stan swojego ucznia. Będzie wiedział, jaki jest jego nastrój oraz najskrytszy ból. Jeśli sam jest doświadczonym w zmaganiach duchowych, to pomoże swemu podopiecznemu i uleczy. Z pewnością, każda choroba, dokładnie zdiagnozowana przez niego z zastosowaniem odpowiednich lekarstw, ustąi"”18.

Starzec nigdy nie potępia grzesznika, nie stroni od niego, nie przekreśla go. Przeciwnie, z całą czułością i łagodnością opatruje jego rany, „niosąc jego duszę na swoich barkach"19. „Jeśli pragniesz leczyć chorych - nauczał św. Izaak Syryjczyk - wiedz, że ludzie dotknięci chorobą bardziej potrzebują bycia pielęgnowanymi niż bitymi. Początkiem mądrości Bożej jest wyrozumiałość i łagodność, która charakteryzuje wielką duszę i niesie na sobie boleści innych"20.

Nie każdy chrześcijanin może zostać starcem. „Starczestwo” jest szczególnym darem Boga. Nie można się nauczyć bycia starcem. Tę łaskę jedynie można otrzymać od Boga. Jest to swego rodzaju przejaw „geniuszu duchowego”, dzięki któremu przewodnik duchowy może rodzić swoich uczniów dla Królestwa Niebieskiego (por. 1 Kor 4,15$)^{21}$. Aby to było możliwe, musi być w posiadaniu trzech szczególnych i nadprzyrodzonych darów. Pierwszym z tych

\footnotetext{
14 Tamże, s. 104. Por. I. SASZKO, Ideat życia monastycznego w Pouczeniach wielebnym mniszkom o tym, czego od nich wymaga życie monastyczne św. Teofana Pustelnika, „Elpis” 21 (2019), s. 79.

${ }^{15}$ СвЯТИТЕЛЬ ФЕОФАН ЗАТВОРНИК, Малые произведения, s. 113-114.

${ }^{16}$ Por. tamże, s. 104.

17 Tamże, s. 142.

${ }^{18}$ Tamże, s. 141.

${ }^{19}$ Tamże, s. 119

${ }^{20}$ J.-C. LARCHET, Terapia chorób duchowych. Wstęp do tradycji ascetycznej Kościoła prawostawnego, tłum. N. Aleksiejuk, Wydawnictwo „Bratczyk”, Hajnówka 2013, s. 418.

${ }^{21}$ Por. Митрополит Антоний СурОжский, Пастырство, издательский дом «Никея», Москва 2017, s. 209.
} 
darów jest dar wglądu duchowego w serce człowieka, który umożliwia rozróżnianie tego wszystkiego, co się w nim kryje, a zwłaszcza nazywania złych myśli (gr. logismoi poneroi) i różnego rodzaju wyobrażeń (gr. fantasiai). Drugi dar to zdolność obdarzania bezwarunkową miłością innego człowieka, co wymaga współodczuwania (gr. syntonia) z nim, utożsamiania się z jego cierpieniem, zgodnie ze słowami św. Pawła Apostoła: „Jeden drugiego brzemiona noście, i tak wypełnijcie prawo Chrystusowe” $(\mathrm{Ga} \mathrm{6,2})^{22}$. „Wgląd w sekrety ludzkich serc, pozbawiony pełnego miłości współodczuwania, nie byłby twórczy, ale zgubny. Jeśli starzec nie miłowałby innych, to nie wystarczyłoby mu sił, aby ich uzdrowić" ${ }^{23}$. Trzecim darem niezbędnym dla każdego duchowego ojca lub duchowej matki jest moc przemieniania otoczenia powierzonych im ludzi. Starzec nie tylko posiada łaskę uzdrawiania oraz wypędzania demonów, lecz również umiejętność ukazywania swym uczniom piękna całego stworzenia, a w nim każdego człowieka, stworzonego na obraz i podobieństwo Boga ${ }^{24}$. Innymi słowy, korzystając $\mathrm{z}$ tego daru, starzec pomaga swoim dzieciom duchowym pokochać to, co niekochane, a także pobłogosławić niepobłogosławione oraz zaakceptować to, co było trudne do zaakceptowania. Mając świadomość wielkiej odpowiedzialności starca za swe duchowe dzieci, św. Teofan stanowczo podkreślał, iż każdy, kto prowadzi innych ku Bogu, ma być osobą charyzmatyczną, jaśniejącą zmartwychwstałym Panem, namaszczoną przez Ducha Świętego, a jednocześnie prowadzącą życie proste, skromne oraz ukryte $^{25}$. Co więcej, ze względu na modlitwę wstawienniczą za swe duchowe dzieci ma być podobny do Mojżesza, natomiast ze względu na czystość swego serca i doskonałość ducha - do Anioła ${ }^{26}$. Prawdziwy i wierny przewodnik duchowy objawia zarówno miłosierne oblicze Boga Ojca, jak i upokorzoną twarz całej ludzkości. W osobie starca otrzymujemy ukojenie, pocieszenie, a także dobrą radę pomocną w każdej sytuacji życiowej. Natomiast wstyd, który odczuwamy, zwierzając się starcowi z popełnionych grzechów i niedoskonałości, stawia go przed nami w pozycji przedstawiciela całej ludzkości, przed którą zostają ujawnione nasze skryte występki ${ }^{27}$.

Święty Teofan odróżniał przewodnictwo duchowe od spowiedzi sakramentalnej. Nauczał, że w celu otrzymania rozgrzeszenia wierny musi udać się do

${ }^{22}$ Por. K. WARE, Przewodnictwo duchowe w prawostawiu, w: K. WARE, Królestwo wnętrza, thum. W. Misijuk, Prawosławna Diecezja Lubelsko-Chełmska, Lublin 2003, s. 190-193.

${ }^{23}$ Tamże, s. 193.

${ }^{24}$ Tamże, s. 194-196.

${ }^{25}$ Por. СвяТИТЕЛЬ ФЕОФАН ЗАТвОРНИК, Малье произведения, s. 114.

${ }^{26}$ Tamże, s. 112-113.

27 Рог. СвятиТЕЛЬ ФЕОФАН ЗАТВОРНИК, О покаянии и причащении. Слова и проповеди, Правило веры, Москва 2017, s. 123-124. 
kapłana. Funkcją starca jest wyłącznie rozeznanie stanu duchowego ucznia oraz udzielanie mu porad i pomocy, aby skutecznie przezwyciężał pokusy, nie popadał w pożądliwości (gr. pathi, cs. strasti) i nie grzeszy ${ }^{28}$. „Starzec to doradca, a nie sędzia. Jego zadaniem jest pocieszanie, wspieranie, dodawanie otuchy, a także powierzanie brata łasce Bożej”29. Na pytanie: „Jaka moc kryje się w starczestwie?” - udzielił on następującej odpowiedzi: „Wielka. Bardzo wielka! Tylko nie ma ono charakteru kanonicznego, lecz posiada charakter duchowy: porady, rozmowy, wsparcie, modlitwy. Zadanie starca polega na tym, aby każdy uczeń odchodził od niego, niczym obmyty, niczym wykąpany"30.

\section{RELACJA MIĘDZY STARCEM A DZIEĆMI DUCHOWYMI}

Warunkiem prawdziwego przewodnictwa duchowego jest nawiązanie głębokiej i zażyłej relacji między uczniem a starcem, którą św. Teofan Pustelnik nie

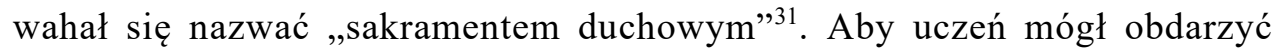
swojego ojca duchowego lub matkę duchową bezwarunkowym zaufaniem, musi czuć się przez niego, czy przez nią akceptowany i miłowany. „Istota przewodnictwa i jego moc polega na tym, iż między starcem a synem przed Obliczem Boga zawiera się «niewidzialna, lecz bardzo owocna» ${ }^{32}$ umowa, na mocy której ojciec bierze na siebie zbawienie swojego ucznia, a uczeń całkowicie powierza się ojcu"33. Opisując tę relację, św. Teofan odwołuje się do pojęcia perychorezy (gr. perichoresis), czyli wzajemnego przenikania się Trzech Osób Boskich. Był on przekonany, iż na wzór Trójcy Przenajświętszej, również między starcem a jego synem duchowym tworzy się „nierozerwalna i serdeczna więź, dzięki której ojciec $\mathrm{z}$ synem, a syn z ojcem duchowo są wzajemnie zjednoczeni (cs. sorastworieny) nie tylko na czas wychowania, lecz na całą wieczność” ${ }^{34}$. Kto zatem jest „zjednoczony miłością ze swoim ojcem, temu nic nie zagraża” 35 . „Będąc pod przewodnictwem ojca duchowego, jak pod

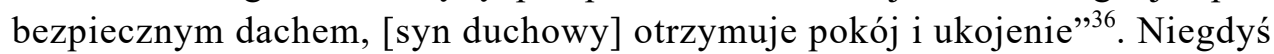

\footnotetext{
${ }^{28}$ Por. СвяТиТЕЛЬ ФЕОФАН ЗАТвоРник, Рукописи из кельи, Правило веры, Москва 2018, s. 692.

${ }^{29}$ Tamże, s. 692-693.

${ }^{30}$ Tamże, s. 694.

${ }^{31}$ СВЯТИТЕЛЬ ФЕОФАН ЗАТВОРНИК, Малые произведения, s. 114.

32 Tamże, s. 150 .

${ }^{33}$ Tamże, s. 117.

${ }^{34}$ Tamże, s. 120

35 Tamże, s. 145 .

${ }^{36}$ Tamże, s. 128.
} 
Bóg, rozmawiając z Mojżeszem, „wziął z ducha, który był w nim i przekazał go siedemdziesięciu starszym", którzy natychmiast zaczęli prorokować (Lb 11, 24-25). Podobnie Bóg czyni ze starcem i jego uczniem - bierze całą duchową moc, a nawet bogactwo darów duchowych, które są w ojcu, i obficie wylewa je na jego syna ${ }^{37}$. Dzięki temu wierny uczeń w przyszłości może stać się kontynuatorem misji i posługi swojego przewodnika duchowego ${ }^{38}$. W tym kontekście warto podkreślić, iż rolą starca nie jest udzielanie uczniowi gotowych odpowiedzi na jego życiowe rozterki i pytania, lecz pomaganie mu w odnalezieniu „wewnętrznego klucza”, dzięki któremu będzie mógł „otwierać w sobie coraz to nowe przestrzenie, aby poddać je ekspansji Ducha" ${ }^{39}$. „Ojciec ma nie tylko wskazywać uczniowi drogę, lecz samemu prowadzić go, a raczej nieść go na sobie" ${ }^{40}$. Co więcej, prawdziwy ojciec duchowy jest zdolny wziąć na siebie także pokusy i grzechy swojego ucznia, będąc świadomy, iż on za nie odpowiada przed Sądem Najwyższego ${ }^{41}$. Święty Teofan przypomniał modlitwę św. Barsanufiusza Wielkiego za jego uczniów: „Panie, albo zaprowadź wraz ze mną także moje dzieci do Królestwa Swojego, albo również i mnie wymaż ze Swojej Księgi Życia" ${ }^{42}$. Ta fraza modlitewna uzmysławia nam, jak wielką miłość, ofiarność i poświęcenie muszą mieć prawdziwi przewodnicy duchowi, którzy troszczą się o swoje dzieci. Tego właśnie nauczał Zbawiciel w Ewangelii według św. Jana: „Nikt nie ma większej miłości od tej, gdy ktoś życie swoje oddaje za przyjaciół swoich” $(\mathrm{J} 15,12)^{43}$. Starzec jest tym, który ogromnie raduje się z każdego, choćby najmniejszego postępu duchowego swojego syna, jak również bardzo cierpi, nawet przelewając w ukryciu gorące łzy, gdy uczeń ulega zgubnym wpływom demona lub nie traktuje poważnie słów i zaleceń swojego ojca. Cierpienie mistrza jest spotęgowane, gdyż niejednokrotnie toczy on potężną walkę duchową z demonami za swojego ucznia oraz w imieniu swojego ucznia. Miał tego świadomość św. Barsanufiusz:

W entuzjazmie swej gorliwości, ojciec duchowy oddaje się w ofierze swoim dzieciom. Jedyną jego troską jest modlić się, pracować, cierpieć, aby móc je ofiarować Bogu w dniu ostatnim, kiedy każdy ze świętych, przyprowadzając do Boga swe dzieci, powie

\footnotetext{
${ }^{37}$ Por. tamże, s. 121.

${ }^{38}$ Por. tamże, s. 127

${ }^{39}$ T. PASZKOwSKa, Psychologia w kierownictwie duchowym, Wydawnictwo KUL, Lublin 2014, s. 167.

${ }^{40}$ СВЯТИТЕЛЬ ФЕОФАН ЗАТВОРНИК, Малые произведения, s. 115.

${ }^{41}$ Por. tamże, s. 117.

42 Tamże, s. 119.

${ }^{43}$ Tamże, s. 118.
} 
dziewiczym głosem, z całą pewnością i wielką wolnością ku zdziwieniu świętych aniołów i wszystkich sił niebiańskich: „Oto ja i dzieci, które dał mi Bóg”"44.

Ze względu na to, że „starzec staje się w pewien sposób pośrednikiem między uczniem a Bogiem: pośrednikiem autentycznym, wiernym i bezpiecznym" ${ }^{45}$, to jest on także celem ogromnej nienawiści i zemsty ze strony Szatana. Pocieszenie duchowe oraz pokój serca, doświadczane przez syna, z reguły jest owocem bólu i łez jego przewodnika duchowego. Nie powinno zatem dziwić, że celem demonów jest osłabienie zażyłej relacji między przewodnikiem duchowym a jego dziećmi. Złe duchy starają się na wszelkie sposoby ostudzić serce ucznia w odniesieniu do mistrza. Czynią, co tylko jest w ich mocy, aby zasiać nieufność, obojętność, zniechęcenie, brak wdzięczności i szacunku. Często przy tym stawiają w złym świetle ojca w oczach syna lub wyolbrzymiają jego ludzkie słabości ${ }^{46}$.

Jeśli przewodnictwo duchowe ma przynieść obfity owoc, którym przede wszystkim jest „przejście ucznia od życia aktywnego do kontemplacji” ${ }^{47}$, to dziecko duchowe ma w odpowiedni sposób odnosić się do swojego starca. Święty Teofan w szczególny sposób zwraca uwagę na trzy najważniejsze zasady, które uczeń ma przestrzegać w relacji ze swym mistrzem. Pierwsza z nich to niepodejmowanie żadnej decyzji bez porady przewodnika duchowego. Dzięki temu uczeń nigdy się nie pomyli, jak również nie da okazji diabłu wprowadzić siebie w błąd. Druga zasada polega na ujawnianiu swoich myśli (gr. logismoi) przed starcem. Te wyobrażeniowe myśli są powiązane z pragnieniami, marzeniami, lękami, obawami i pożądliwościami (gr. pathi). Jeśli pozwolimy zatem swojemu przewodnikowi spojrzeć w nasze duchowe wnętrze, to możemy być pewni, że z miłością pomoże nam uporządkować duchowy zamęt, a jego wsparcie, modlitwa i słowo uzdrowią nasze rany ${ }^{48}$. „Czasami chorzy na ciele w ogóle nie odczuwają, że im cokolwiek dolega. Jednak ufają bardziej lekarzowi niż własnemu odczuciu. Podobnie jest w życiu duchowym. Z tego względu otwórz przed ojcem swoje serce, a on je zdiagnozuje i uleczy" - zalecał św. Teofan Pustelnik ${ }^{49}$. Dobrze jest na samym początku znajomości opowiedzieć przewodnikowi duchowemu całe swoje życie, a potem nieustannie pokornie opowiadać mu o wszystkim ${ }^{50}$. Należy pamiętać, że „każda skrytość

\footnotetext{
${ }^{44}$ MniszKa NikoŁaja, Prawostawna tradycja ojcostwa duchowego, Białystok 2015, s. 46.

${ }^{45}$ СвЯТИТЕЛЬ ФЕОФАН ЗАТВОРНИК, Малые произведения, s. 119.

${ }^{46}$ Por. tamże, s. 123-125.

47 Tamże, s. 145.

${ }^{48}$ Tamże, s. 130-132, 161.

49 Tamże, s. 132.

${ }^{50}$ Por. tamże, s. 133.
} 
jest dziełem szatańskim”, a każda „myśl ukryta, jest myślą cudzołożną"52. Demony bardzo się boją szczerości między ludźmi, gdyż ona demaskuje ich zasadzki ${ }^{53}$. Uczeń, który bez żadnych zastrzeżeń otwiera przed ojcem duchownym swoje serce, dostępuje oczyszczenia i uzdrowienia ${ }^{54}$. „Jak czyste płótno w rękach malarza, albo jak dobra glina w rękach garncarza - tak uczeń w rękach swojego ojca" - mawiał św. Teofan ${ }^{55}$. W Ewangelii według św. Łukasza Jezus objawił swoim uczniom: „Kto was słucha, Mnie słucha” (Łk 10, 16). Autor Listu do Hebrajczyków przestrzegał, aby „nie zapominać o wzajemnej więzi”, a także okazywać posłuszeństwo swoim przełożonym, gdyż „oni czuwają nad duszami" naszymi i muszą zdać z tego sprawę przed Bogiem (Hbr 13, 16-17). Nawiązując do tych słów, św. Teofan sformułował trzecią zasadę, której mają przestrzegać uczniowie w relacji do swych starców. Jest nią posłuszeństwo. Co jest istotą posłuszeństwa? Być posłusznym oznacza być bardzo twórczym w słuchaniu. Jedynie osoba wewnętrznie wolna może okazywać prawdziwe posłuszeństwo wobec przewodnika, czyniąc to $z$ radością i miłością. Wie bowiem, iż ojciec nigdy jej nie skrzywdzi, a jego wymagania, niekiedy nawet bardzo surowe, przyczynią się do osiągnięcia dojrzałości i wzrostu duchowego. Uczeń, który okazuje doskonałe posłuszeństwo swojemu przewodnikowi, szybko osiąga stan wewnętrznego pokoju, stając się prosty, jak dziecko (por. Mt 18, 3) ${ }^{56}$. „Celem posłuszeństwa jest nauczenie człowieka, w jaki sposób oderwać się od własnych myśli (gr. logismoi), a także zdystansować się do osobistych osądów rzeczywistości oraz uważnie wsłuchiwać się w to, co mówi mu inny człowiek" $" 57$.

Jaki piękny charakter kształtuje się u tego, który powierzył się doświadczonemu przewodnikowi duchowemu! Najpierw kształtuje się w nim pokora, przez pokorę beznamiętność, wyciszenie wewnętrzne, a także pojawia się Światłość Boża. Następnie - prostota, łagodność i dziecięctwo duchowe. Stopniowo człowiek osiąga miarę samego Chrystusa $^{58}$.

Zatem, podkreślając ogromną moc orędownictwa starca za swoje dzieci duchowe, św. Teofan Pustelnik zachęcał również uczniów, aby nie ustawali

\footnotetext{
51 Tamże.

52 Tamże, s. 140.

53 Tamże, s. 133.

54 Tamże, s. 135.

55 Tamże, s. 117.

${ }^{56}$ Tamże, s. 134-138.

${ }^{57}$ Por. В. ЗЕлинский, Дружба как духовничество, s. 60.

${ }^{58}$ СВяТИТЕЛЬ ФЕОФАН ЗАТВОРНИК, Малье произведения, s. 146-147.
} 
w modlitwach za swoich mistrzów, wypraszając dla nich dar Ducha Świętego, dzięki czemu będą mogli mądrze i roztropnie nimi kierować ${ }^{59}$. Modlitwa wstawiennicza tworzy głęboką nadprzyrodzoną jedność i wspólnotę między starcem a jego duchowymi dziećmi.

\section{PRZYJAŹŃ JAKO RODZAJ PRZEWODNICTWA DUCHOWEGO}

Nie jest możliwe zrozumienie innej osoby ludzkiej na odległość. Im bardziej chcemy poznać drugiego człowieka, tym w bardziej zażyłą i serdeczną relację mamy z nim wejść. Celem jest stanie się przyjaciółmi, gdyż to właśnie relacja przyjaźni najlepiej odzwierciedla misterium Trójcy Przenajświętszej ${ }^{60}$. Podobnie mistrz duchowy nie będzie w stanie przekazać wiedzy i doświadczenia swoim uczniom, jeśli nie będzie spędzał z nimi wspólnego czasu i nie wejdzie z nimi w zażyłą wspólnotę (gr. koinonia). Grecki wyraz filia, używany na określenie miłości przyjacielskiej, podkreśla ontologiczny charakter takiej więzi. Nazywając swych uczniów przyjaciółmi, Jezus okazuje im zaufanie: „Nazwałem was przyjaciółmi, albowiem oznajmiłem wam wszystko, co usłyszałem od Ojca Mego" (J 15, 15) ${ }^{61}$.

Wybitny historyk chrześcijaństwa, Robert Louis Wilken, zwraca uwagę na szczególną przyjaźń, która cechowała relacje Orygenesa z jego uczniami, a zwłaszcza ze św. Grzegorzem Cudotwórcą. Ów Święty w Mowie pochwalnej ku czci Orygenesa określił swojego mistrza jako ,przyjaciela i tłumacza Słowa”: „Przyjaźń jest wrażliwością i czułością, ciepłem i miłością, która objawiała się w słowach nauczyciela i jego relacji z nami”. Zatem podobnie jak serce Jonatana było przywiązane do Dawida, tak serce św. Grzegorza Cudotwórcy - do Orygenesa. Orygenes był bowiem mędrcem, który nauczał bardziej własnym przykładem, dobrocią i troską o swoich uczniów niż słowami. Miłość Orygenesa do uczniów była najważniejszą częścią procesu kształcenia i wychowywania. „Kochał on głęboko, dzielił się tym, co najbardziej osobiste, a także zadawał pytania, wyrażał poglądy i słuchał odpowiedzi swoich uczniów". Innymi słowy, pragnął, aby jego uczniowie przynosili dobre i obfite owoce.

\footnotetext{
${ }^{59}$ Por. tamże, s. 129.

${ }^{60}$ Por. М. АКСенов-МеРСон, Я назвал вас друзьями (Ин. 15,15), w: Дружба: ее формы, испытания и дары, ред. К. Сигов, Дух і Літера, Киев 2008, s. 33.

${ }^{61}$ Por. tamże.
} 
On bardzo o nas się troszczył, lecz jemu przeszkadzały nasz upór oraz lenistwo duchowe ${ }^{62}$.

Warto zauważyć, że również św. Teofan Pustelnik porównywał relacje uczniów ze swoim przewodnikiem duchowym do głębokiej duchowej przyjaźni. Co więcej, taka relacja z mądrym i pełnym Ducha Świętego przyjacielem może zastąpić przewodnictwo duchowe, w klasycznym rozumieniu tego pojęcia. Na potwierdzenie tego przywoływał perykopę z Księgi Syracha:

Wierny przyjaciel potężną obroną, kto go znalazł, skarb znalazł. Za wiernego przyjaciela nie ma odpłaty, ani równej wagi za wielką jego wartość. Wierny przyjaciel jest lekarstwem życia; znajdują go bogobojni. Bogobojny dobrze pokieruje swoją przyjaźnią, bo jaki jest on, taki jego przyjaciel (Syr 6, 14-17).

Powyższe cechy prawdziwego przyjaciela można odnieść do osoby starca. Przewodnik duchowy, podobnie jak przyjaciel, jest dla swoich uczniów obrońcą, mistrzem, lekarzem, a więc największym skarbem na drodze do Nieba. „Bóg naprawdę działa przez prawdziwego przyjaciela” - przekonywał św. Teofan Pustelnik. $Z$ tego powodu należy mu powierzać wszelkie trudności i wątpliwości ${ }^{63}$, a także ,żyć z nim dusza w duszę" ${ }^{34}$. Wzór prawdziwego przyjaciela, a także mistrza duchowego mamy w Osobie naszego Pana. Pamiętajmy, że Jezus umył swoim uczniom nogi (J 13) ${ }^{65}$. Piękną ilustracją relacji przyjaźni może być koptyjska ikona z VII w., która ukazuje Chrystusa trzymającego rękę na ramieniu swojego nieznanego przyjaciela. „Poprzez ten gest, Chrystus bierze na siebie ciężar swojego przyjaciela, jego błędy oraz wszystko, co go obciąża" ${ }^{66}$. On nie stoi naprzeciwko przyjaciela, lecz idzie obok niego; jest $\mathrm{z}$ nim ramię $\mathrm{w}$ ramię, towarzysząc mu w drodze ${ }^{67}$. $\mathrm{Z}$ pewnością, bardzo dobrze zrozumiał to również św. Teofan, skoro tak stanowczo przekonywał, iż

[...] będzie to bardzo owocne, jeśli ktoś znajdzie jednego doradcę oraz serdecznie z nim się zjednoczy, a także będzie z nim żyć we wzajemnej szczerości i otwartości oraz

\footnotetext{
${ }^{62}$ Р.Л. ВилКЕН, У пошуках обличчя, s. 263-266.

${ }^{63}$ СвяТИТЕЛЬ ФЕОФАН ЗАТВОРНИК, Малые произведения, s. 162-167.

64 Tamże, s. 168.

${ }^{65}$ Por. В. ЗЕлинский, Дружба как духовничество, s. 55-56.

${ }^{66}$ БРАТ РОЖЕ 3 ТЕЗЕ, Проста довіра. Вибрані тексти, переклад С. Желдак, Я. Вестель, В. Резніченко, Дух і Літера, Київ 2012, s. 128-129.

${ }^{67}$ Por. tamże, s. 129.
} 
wzajemnej przyjaźni. Niech więc siebie nawzajem prowadzą i sobie doradzają. [...] Albowiem obiecał Bóg, że będzie obecny pośród dwóch zebranych w Jego Imię ${ }^{68}$.

Zdaniem św. Teofana otwieranie serca przed przewodnikiem duchowym ma prowadzić do ukojenia i pocieszenia strapionego serca. Albowiem poprzez swoją dobroć, wrażliwość oraz modlitwę starzec jest w stanie odciążyć syna, dać mu nadzieję, uleczyć jego ranę, wskazać mu wyjście z trudnej sytuacji. W Księdze Wyjścia możemy przeczytać o tym, jak Bóg rozmawiał z Mojżeszem na Synaju: „twarzą w twarz, jak się rozmawia z przyjacielem” (Wj 33, 11). Do takiego właśnie przyjacielskiego dialogu zaprasza św. Teofan starców oraz ich duchowe dzieci. Każde skrępowanie ucznia, wyrażające się zamknięciem na szczerą rozmowę ze swoim mistrzem, może zablokować działanie Ducha Świętego. Wszak „uleczyć można tylko otwartą ranę, obmyć można tylko odsłoniętą nieczystość, a rozwiązać - tylko pokazane kajdany"69.

Duchowa rozmowa ucznia ze starcem jest rozmową, której źródłem jest modlitwa. Dojrzały i doświadczony w ascetycznych zmaganiach ojciec duchowy, jak również dojrzała i doświadczona $\mathrm{w}$ ascetycznych zmaganiach matka duchowa to osoby, które będąc w jedności z Bogiem, mogą wprowadzić swoje duchowe dziecko w uzdrawiającą obecność Bożego Ducha.

W obecnym czasie wielkiego postępu technicznego i naukowego ludzie coraz bardziej czują się samotni i bezradni. Zapewne ma na to wpływ rozluźnienie się bezpośrednich relacji międzyosobowych oraz komunikacja w świecie wirtualnym. Globalne przemiany polityczne, kulturowe i religijne są nacechowane ustawicznym oraz ciągle pogłębiającym się kryzysem. Człowiek staje się coraz bardziej niezdolny do nawiązywania i podtrzymywania relacji międzyludzkich. Żyjąc na pokaz, wewnętrznie doświadcza pustki i niezrozumienia. Choć ma nieustanny dostęp do aktualnych informacji o tym, co się dzieje w świecie, nie potrafi znaleźć odpowiedzi na nurtujące go pytania egzystencjalne. Doświadcza głębokiego wewnętrznego rozdarcia, które św. Jan Paweł II określił jako „ból duszy”. Jest to ból „,natury duchowej”, a nie tylko „psychicznej”, który „[...] towarzyszy cierpieniu zarówno moralnemu, jak i fizycznemu. Rozległość i wielorakość cierpienia moralnego jest z pewnością

\footnotetext{
${ }^{68}$ СВЯТИТЕЛЬ ФЕОФАН ЗАТВОРНИК, Малые произведения, s. 165-166.

${ }^{69}$ TENŻE, O покаянии и причащении, s. 122-123.
} 
nie mniejsza niż fizycznego, równocześnie zaś zdaje się ono jakby mniej zidentyfikowane i mniej objęte terapią" ${ }^{, 70}$. Kryzysu egzystencjalnego doświadczają nie tylko osoby świeckie, żyjące w społeczeństwie naznaczonym konsumpcją czy hedonizmem, lecz coraz częściej także osoby duchowne kapłani, mnisi oraz mniszki, którzy sami powołani są do okazywania duchowej pomocy innym. Coraz więcej ludzi zwraca się po pomoc psychologiczną czy psychoterapeutyczną. Często jednak pomoc świadczona w różnego rodzaju gabinetach lekarskich i terapeutycznych nie daje oczekiwanej ulgi $\mathrm{w}$ cierpieniu. Zapewne wynika to $\mathrm{z}$ faktu, że istota ich wszystkich problemów ma swoje źródło w utraconej relacji z Bogiem. Gdy przyjrzymy się współczesnym ludziom, to zauważymy, że są ,podobni w swych rozczarowaniach do uczniów zmierzających do Emaus" - potrzebują duchowego przyjaciela, który na trudnej drodze życiowych doświadczeń „wysłucha ich oczekiwań i pragnień oraz w kluczu Słowa je zinterpretuje" ${ }^{71}$.

Obecny kryzys egzystencjalny, a zwłaszcza utrata celu i sensu życia, jaki niestety jest również udziałem wielu chrześcijan, coraz bardziej skłania do tego, aby czerpać z wielowiekowej praktyki przewodnictwa duchowego. Skorzystać możemy również z mądrości św. Teofana Pustelnika, który w swoich dziełach odwoływał się do wielkich mistrzów życia duchowego z minionych wieków oraz własnego doświadczenia bycia ojcem duchowym dla swoich uczniów. Kierownictwo duchowe może pomóc współczesnemu chrześcijaninowi w odnalezieniu swojej osobowej tożsamości w Bogu, a co za tym idzie - w odzyskaniu pełnego uzdrowienia. Ze względu na to, że człowiek jest osobą duchowo-psychofizyczną, „Duch Święty, Który jest Dawcą wszelkiego rodzaju zdrowia", posługuje się rozmową duchową, aby spowodować poprawę w sferze ducha, psychiki i ciała ${ }^{72}$. We współczesnym Kościele zauważalna jest coraz to większa potrzeba przewodnictwa duchowego, zarówno dla osób duchowych, jak i wiernych świeckich. W monasterach i seminariach duchowych, a także w poszczególnych parafiach niezbędna jest dobra formacja duchowa, której podstawą jest Dobra Nowina. Nie wystarczy pomoc psychologiczno-psychoterapeutyczna, świadczona przez wykwalifikowany personel, gdyż człowiek jest nie tylko bytem fizyczno-psychicznym, lecz także duchowym.

\footnotetext{
${ }^{70}$ JAN PAWEŁ II, List apostolski „Salvifici doloris”, s. 5, http://www.documenta-catholica.eu/d_1 983-02-11-\%20SS\%20Ioannes\%20Paulus\%20II\%20-\%20Salvifici\%20Doloris\%20-\%20PL.pdf (dostęp: 21.08.2020).

${ }^{71}$ T. PASZKOwSKa, Psychologia w kierownictwie duchowym, s. 12.

${ }^{72}$ L.J. GoNZÁLEZ, Terapia duchowa. Ludzkie i duchowe uzdrowienie z chorób duszy, tłum. D. Kucała, Wydawnictwo Światło-Życie, Kraków 2005, s. 211-212.
} 
Kościół powinien więc przygotowywać prawdziwych „duchowych lekarzy”73. Święty Paweł zalecał, aby modlić się i starać się „o większe dary”, które przyczyniłyby się „do zbudowania Kościoła” (1 Kor 12, 31; 14, 12). A wszystko po to, aby w chwili eschatologicznego spotkania $\mathrm{z}$ Boskim Lekarzem (gr. Iatros) nie okazało się, że wśród całych zastępów ludzi Kościoła nie ma nikogo, kto by wprowadził Jego poranionych braci i siostry do sadzawki Betesdy (por. J 5, 1-9) ${ }^{74}$.

\section{BIBLIOGRAFIA}

Аксенов-Мерсон М., Я назвал вас друзьями (Ин. 15,15), w: Дружба: ее формы, испытания и дары, ред. Константин Сигов, Дух і Літера, Киев 2008, s. 29-50 [Aksenov-Merson М., Ya nazval vas druz'yami (In. 15,15), w: Druzhba: yeye formy, ispytaniya i dary, red. Konstantin Sigov, Dukh i Litera, Kiyev 2008, s. 29-50].

БРАТ РОЖЕ 3 ТЕЗЕ, Проста довіра. Вибрані тексти, переклад Світлана Желдак, Яна Вестель, Вікторія Резніченко, Дух і Літера, Київ 2012 [Brat Rozhe z Teze, Prosta dovira. Vybrani teksty, pereklad Svitlana Zheldak, Yana Vestel', Viktoriya Reznichenko, Dukh i Litera, Kyyiv 2012].

ВілКен Р. Л., У пошуках обличчя Божого. Введення у богослов'я ранньої Церкви, Видавництво українського католицького університету, Львів 2005 [Vilken R. L., U poshukakh oblychchya Bozhoho. Vvedennya u bohoslov"ya rann'oyi Tserkvy, Vydavnytstvo ukrayins'koho katolyts'koho universytetu, L'viv 2005].

ВлАДИМИР Л., Оптинские старцы, w: TENŻE, На стражи истины, Стретенский монастырь, Москва 2007, s. 22-91 [Vladimir L., Optinskiye startsy, w: TENŻE, Na strazhi istiny, Stretenskiy monastyr', Moskva 2007, s. 22-91]

Сурожский А., митрополит, Пастырство, Издательский дом «Никея», Москва 2017 [Surozhskiy A., mitropolit, Pastyrstvo, Izdatel'skiy dom «Nikeya», Moskva 2017].

СвятитЕЛЬ ФЕОФАН ЗАТвОРник, Малые произведения, Правило веры, Москва 2018 [Svyatitel' Feofan Zatvornik, Malyye proizvedeniya, Pravilo very, Moskva 2018].

СвятИТЕЛЬ ФЕОФАН ЗАТВОРник, О покаянии и причащении. Слова и проповеди, Правило веры, Москва 2017 [Svyatitel' Feofan Zatvornik, O pokayanii i prichashchenii. Slova i propovedi, Pravilo very, Moskva 2017].

СвЯтИТЕЛЬ ФЕОФАН ЗАТвоРник, Рукописи из кельи, Правило веры, Москва 2018 [Svyatitel' Feofan Zatvornik, Rukopisi iz kel'i, Pravilo very, Moskva 2018].

СвятиТЕЛЬ ФЕОФАН ЗАТВоРник, Что есть духовная жизнь и как на нее настроиться? Собрание писем, Правило веры, Москва 2017 [Svyatitel' Feofan Zatvornik, Chto yest' dukhovnaya zhizn' i kak na neye nastroit'sya? Sobraniye pisem, Pravilo very, Moskva 2017].

ЗЕлинский В., Дружба как духовничество, w: Дружба: ее формы, испытания и дары, ред. К. Сигов, Дух і Літера, Киев 2008, s. 51-60 [Zelinskiy V., Druzhba kak dukhovnichestvo, w: Druzhba: yeye formy, ispytaniya i dary, red. K. Sigov, Dukh i Litera, Kiyev 2008, s. 51-60].

\footnotetext{
73 ТЕОФАН ЗАТВОРНИК, Нагадування всечесним монахиням про те, чого від них вимагає чернецтво, перклад М. Лемик, Свічадо, Львів 2007, s. 78.

${ }^{74}$ Por. tamże, s. 74.
} 
ФлорОвский Г., Пути русского богословия, Издательство «Тираж-51», Краматорск 2012 [Florovskiy G., Puti russkogo bogosloviya, Izdatel'stvo «Tirazh-51», Kramatorsk 2012].

КАРФИКОВА Л., Святитель Григорий Нисский. Бесконечность Бога и бесконечный путь к Нему человека, перевод Илья Бей, Дух і Літера, Киев 2012 [Karfikova L., Svyatitel' Grigoriy Nisskiy. Beskonechnost' Boga i beskonechnyy put' k Nemu cheloveka, perevod Il'ya Bey, Dukh i Litera, Kiyev 2012].

НЕмБРини Ф., От отца к сыну. Беседы о рискованном деле воспитания, перевод. Екатерина Бровко, Дух і Літера, Киев 2015 [Nembrini F., Ot ottsa k synu. Besedy o riskovannom dele vospitaniya, perevod. Yekaterina Brovko, Dukh i Litera, Kiyev 2015].

ТЕОФАН ЗАТвоРник, Нагадування всечесним монахиням про те, чого від них вимагає чернецтво, перклад Мирослав Лемик, Свічадо, Львів 2007 [Teofan Zatvornyk, Nahaduvannya vsechesnym monakhynyam pro te, choho vid nykh vymahaye chernetstvo, perklad Myroslav Lemyk, Svichado, L'viv 2007].

GonZÁLEz L.J., Terapia duchowa. Ludzkie i duchowe uzdrowienie z chorób duszy, tłum. D. Kucała, Wydawnictwo Światło-Życie, Kraków 2005.

JAN PAWEŁ II, List apostolski „Salvifici doloris”, s. 5, http://www.documenta-catholica.eu/d 1983-02-11-\%20SS\%20Ioannes\%20Paulus\%20II\%20\%20Salvifici\%20Doloris\%20-\%20PL.pdf (dostęp: 21.08.2020).

LARChET J.-C., Terapia chorób duchowych. Wstęp do tradycji ascetycznej Kościoła prawosławnego, tłum. N. Aleksiejuk, Wydawnictwo „Bratczyk”, Hajnówka 2013.

Merton T., Kierownictwo duchowe i medytacja, tłum. W. Grzybowski, Wydawnictwo M, Kraków 1995.

MisıJUK W., Przewodnictwo duchowe w monastycyzmie prawosławnym, Prawosławna Diecezja Lubelsko-Chełmska, Lublin 2014.

MnisZKA NiKOŁAJA, Prawosławna tradycja ojcostwa duchowego, Wydawnictwo Uniwersytetu w Białymstoku, Białystok 2015.

PASZKOwSKa T., Psychologia w kierownictwie duchowym, Wydawnictwo KUL, Lublin 2014.

SASZKo I., Ideał życia monastycznego w Pouczeniach wielebnym mniszkom o tym, czego od nich wymaga życie monastyczne św. Teofana Pustelnika, „Elpis” 21 (2019), s. 79-86.

WARE K., Przewodnictwo duchowe w prawosławiu, w: K. WARE, Królestwo wnętrza, thum. W. Misijuk, Prawosławna Diecezja Lubelsko-Chełmska, Lublin 2003, s. 178-210.

\section{PRZEDWODNICTWO DUCHOWE \\ W ŚWIETLE NAUCZANIA ŚW. TEOFANA PUSTELNIKA}

Streszczenie

Święty Teofan Pustelnik (1815-1894) był rosyjskim ascetą, pustelnikiem, a jednocześnie biskupem i teologiem. Zarówno w swoich kazaniach, jak i w licznej korespondencji zachęcał do korzystania z przewodnictwa duchowego, udzielanego wiernym przez mnichów, mniszki oraz kapłanów. Dawał też wskazówki przewodnikom duchowym, w jaki sposób mają sprawować posługę, do której zostali powołani. Nawiązując do tradycji Kościoła głosił, iż relacja między starcem a jego uczniami ma być oparta na zażyłej i serdecznej przyjaźni. Jeśli ktoś nie ma możliwości znalezienia doświadczonego ojca duchowego, to na drodze ku wieczności pomocni mogą być jego przyjaciele.

Słowa kluczowe: św. Teofan Pustelnik; przewodnictwo duchowe; starzec; przyjaciel. 